\title{
Pengembangan potensi ekowisata untuk meningkatkan perekonomian masyarakat Desa Mempura Kabupaten Siak di masa Pandemi Covid-19
}

\author{
Cisilia Maiyori* \\ Universitas Lancang Kuning \\ * cisiliamaiyori@unilak.ac.id
}

\begin{abstract}
Abstrak. Kebijakan Pemerintah Kabupaten Siak menutup objek wisata Istana Kerajaan Siak Sri Indrapura untuk mencegah penyebaran wabah Covid-19 berdampak terhadap perekonomian masyarakat, termasuk masyarakat Desa Mempura. Pengabdian ini bertujuan untuk membantu mengembangkan potensi ekowisata untuk meningkatkan perekonomian masyarakat Desa Mempura di masa pandemi Covid-19. Metode pelaksanaan yang digunakan dalam kegiatan pengabdian ini menggunakan metode ceramah disertai dialog secara langsung dengan masyarakat. Kabupaten Siak telah dikenal masyarakat, baik nasional maupun internasional, dengan objek wisata Istana Kerajaan Siak Sri Indrapura yang terkenal akan kejayaan serta peninggalan bersejarahnya yang kental dengan corak budaya Melayu yang berpadu nuansa Islam. Sebenarnya, selain wisata sejarah, bentangan alam Kabupaten Siak yang indah dan asri sangat potensial menjadi kawasan ekowisata yang menjanjikan. Apalagi di saat kondisi perekonomian masyarakat sedang memburuk akibat pandemi Covid-19 yang melanda selama beberapa bulan terakhir. Upaya yang dilakukan oleh tim pengabdi adalah memberikan penyuluhan hukum mengenai ekowisata untuk membantu masyarakat mengembangkan potensi ekowisata di Desa Mempura. Dalam mengembangkan sebuah kawasan ekowisata, diperlukan adanya dukungan yang nyata dari Pemerintah Kabupaten Siak sebagai wujud keberpihakan pemerintah terhadap peningkatan perekonomian masyarakat.
\end{abstract}

Kata kunci: ekowisata, perekonomian masyarakat, Desa Mempura

\begin{abstract}
The Siak Regency Government's policy to close the tourist attraction of the Siak Sri Indrapura Royal Palace to prevent the spread of the Covid-19 outbreak has an impact on the economy of the community, including the people of Mempura Village. This service aims to help develop ecotourism potential to improve the economy of the Mempura Village community during the Covid-19 pandemic. The method of implementation used in this service activity uses the lecture method accompanied by direct dialogue with the community. Siak Regency has been known to the public, both nationally and internationally, with the tourist attraction of the Siak Sri Indrapura Royal Palace which is famous for its glory and historical heritage that is thick with Malay cultural features that blend Islamic nuances. In fact, apart from historical tourism, the beautiful and luscious landscape of Siak Regency has the potential to become a promising ecotourism area. Especially when people's economic conditions are deteriorating due to the Covid-19 pandemic that has hit during the last few months. The effort made by the service team is to provide legal counseling on ecotourism to help the community develop the potential for ecotourism in Mempura Village. In developing an ecotourism area, real support from the Siak Regency Government is needed as a form of the government's support for improving the community's economy.
\end{abstract}

Keywords: ecotourism, community economy, Mempura Village

To cite this article: Maiyori, C. 2020. Pengembangan potensi ekowisata untuk meningkatkan perekonomian masyarakat Desa Mempura Kabupaten Siak di masa Pandemi Covid-19. Unri Conference Series: Community Engagement 2: 440-444. https://doi.org/10.31258/unricsce.2.440-444

(C) 2020 Authors

Peer-review under responsibility of the organizing committee of Seminar Nasional Pemberdayaan Masyarakat 2020 


\section{PENDAHULUAN}

Pemahaman terhadap ekowisata berjalan mengikuti kemajuan pembangunan ekonomi, ilmu pengetahuan dan teknologi, serta peningkatan kesadaran global terhadap aspek lingkungan. Pemahaman tersebut mengungkap makna penting perihal nilai-nilai budaya lokal dan hubungannya dengan pengelolaan lingkungan. Nilai-nilai lokal secara ekologi telah terbukti sebagai komponen penting upaya konservasi keanekaragaman hayati. Kerangka berpikir tersebut menjadi landasan tersusunnya definisi dari ekowisata. Di Indonesia, taman nasional merupakan kawasan konservasi terpenting yang mengoperasikan kegiatan-kegiatan ekowisata. Dalam Undang-Undang Nomor 10 Tahun 2009 tentang Kepariwisataan dijelaskan bahwa pariwisata adalah berbagai macam kegiatan wisata dan didukung oleh berbagai fasilitas serta layanan yang disediakan masyarakat, pengusaha, pemerintah pusat, dan pemerintah daerah.

Salah satu pandangan yang tepat untuk dijadikan acuan dalam pengembangan wilayah untuk wisata adalah ekowisata. Ekowisata, seperti halnya pariwisata, mempunyai dua arti penting yaitu sebagai perilaku dan sebagai industri. Ekowisata sebagai perilaku merupakan sikap dari para pelaku pariwisata dalam mengembangkan pariwisata di kawasan hutan. Ekowisata sebagai industri diartikan bahwa pemerintah, pihak swasta, maupun masyarakat harus bersama-sama mengembangkan suatu mekanisme pariwisata yang memberikan manfaat secara ekonomi, sosial dan budaya, serta bermanfaat bagi masyarakat setempat.

Tujuan kebijakan umum pengembangan ekowisata dilakukan dalam rangka mewujudkan kelestarian sumber daya alam hayati dan keseimbangan ekosistemnya sehingga dapat mendukung upaya peningkatan kesejahteraan masyarakat. Seiring dengan pemberlakuan otonomi daerah, memberikan kesempatan kepada pemerintah daerah dalam melakukan perencanaan kegiatan pembangunan secara mandiri sehingga diharapkan mampu mengoptimalkan setiap sumber daya yang dimilikinya bagi pembangunan berkelanjutan yang berwawasan lingkungan.

Salah satu daerah yang potensial dikembangkan menjadi kawasan ekowisata di Provinsi Riau adalah Kabupaten Siak. Saat ini Kabupaten Siak telah dikenal masyarakat, baik nasional maupun internasional, dengan objek wisata Istana Kerajaan Siak Sri Indrapura yang terkenal akan kejayaan serta peninggalan bersejarahnya yang kental dengan corak budaya Melayu yang berpadu nuansa Islam. Sebenarnya, selain wisata sejarah, bentangan alam Kabupaten Siak yang indah dan asri sangat potensial menjadi kawasan ekowisata yang menjanjikan. Salah satunya adalah Desa Mempura.

Desa Mempura merupakan salah satu desa yang ada di Kecamatan Mempura. Desa Mempura berjarak lebih kurang 8 Kilometer dari Kota Siak Sri Indrapura yang merupakan ibukota Kabupaten Siak. Apabila ditempuh menggunakan transportasi darat, dari Desa Mempura ke Kota Siak Sri Indrapura hanya memakan waktu lebih kurang 10 menit. Masyarakat Desa Mempura banyak yang beraktivitas hingga bekerja dan berwirausaha di Kota Siak Sri Indrapura. Oleh karena itu, kebijakan Pemerintah Kabupaten Siak yang menutup objek wisata Istana Kerajaan Siak Sri Indrapura dan objek-objek wisata sejarah lainnya yang terdapat di Kota Siak Sri Indrapura selama beberapa bulan terakhir untuk mencegah terjadinya penyebaran wabah Covid-19 sangat berdampak terhadap perekonomian masyarakat Desa Mempura.

Terhampar di sepanjang tepian Sungai Siak, Desa Mempura sebenarnya merupakan salah satu kawasan yang potensial dijadikan sebagai kawasan ekowisata. Meskipun demikian, sejauh ini ternyata belum ada kawasan ekowisata di Desa Mempura. Objek wisata yang ada di Desa Mempura hanya Tangsi Militer Belanda sebagai objek wisata sejarah. Permasalahannya adalah ketidaktahuan masyarakat mengenai ekowisata. Oleh karena itu, pengabdian ini bertujuan untuk membantu mengembangkan potensi ekowisata untuk meningkatkan perekonomian masyarakat Desa Mempura di masa pandemi Covid-19.

\section{METODE PENERAPAN}

Metode pelaksanaan yang digunakan dalam kegiatan pengabdian kepada masyarakat ini menggunakan metode ceramah disertai dialog secara langsung dengan masyarakat Desa Mempura Kabupaten Siak. Untuk mengukur tingkat pemahaman peserta, tim pengabdi membagikan kuesioner yang berisi 3 (tiga) pertanyaan kepada peserta sebelum penyuluhan hukum dimulai lalu meminta para peserta untuk mengisi kuesioner tersebut dan mengumpulkannya kepada tim pengabdi. Setelah penyuluhan hukum selesai, tim pengabdi kembali membagikan kuesioner yang sama kepada para peserta untuk diisi dan dikumpulkan kembali kepada tim pengabdi. Keberhasilan kegiatan penyuluhan hukum ini dilihat dari pemahaman peserta terhadap materi yang diberikan. 


\section{HASIL DAN KETERCAPAIAN SASARAN}

Ekowisata adalah perjalanan wisata ke suatu lingkungan alam yang alami maupun buatan serta kebudayaan yang bersifat informatif dan partisipatif yang bertujuan untuk menjamin kelestarian alam serta sosial dan budaya. Ekowisata menitikberatkan pada tiga hal utama, yaitu keberlangsungan alam atau ekologi, memberi manfaat ekonomi, dan secara psikologis dapat diterima dalam kehidupan sosial masyarakat.

Wunder (2000) mendefinisikan ekowisata sebagai wisata yang bertanggung jawab terhadap lingkungan, memberikan dampak langsung terhadap konservasi kawasan, berperan dalam usaha-usaha pemberdayaan ekonomi masyarakat lokal, serta mendorong konservasi dan pembangunan berkelanjutan. Sedangkan Cruz (2005) mendefinisikan ekowisata sebagai pariwisata yang memperhatikan lingkungan, perjalanan wisata yang masih alami tanpa mengakibatkan gangguan dengan tujuan menikmati, mencari pengalaman, dan mempelajari keindahan alam yang ada di daerah tersebut.

Ekowisata berpijak pada tiga kaki sekaligus, yaitu wisata pedesaan, wisata alam, dan wisata budaya. Dalam Deklarasi Quebec tahun 2002 disimpulkan bahwa ekowisata merupakan sustainable tourism yang secara spesifik memuat upaya-upaya (Sunaryo, 2015):

1. Kontribusi aktif dalam konservasi alam dan budaya

2. Partisipasi penduduk lokal dalam perencanaan, pembangunan, dan operasional kegiatan wisata serta menikmati kesejahteraan.

3. Transfer pengetahuan tentang warisan budaya dan alam kepada pengunjung.

4. Bentuk wisata independen atau kelompok wisata berukuran kecil.

Meskipun pengertian tentang ekowisata mengalami perkembangan dari waktu ke waktu, namun pada hakikatnya, ekowisata adalah suatu bentuk wisata yang bertanggung jawab terhadap kelestarian area yang masih alami, memberi manfaat secara ekonomi, dan mempertahankan keutuhan budaya bagi masyarakat setempat. Atas dasar itulah maka bentuk ekowisata pada prinsipnya merupakan bentuk gerakan konservasi yang dilakukan oleh masyarakat.

Peraturan Menteri Dalam Negeri Nomor 33 Tahun 2009 tentang Pedoman Pengembangan Ekowisata di Daerah memberikan definisi bahwa ekowisata adalah kegiatan wisata alam di daerah yang bertanggung jawab dengan memperhatikan unsur pendidikan, pemahaman, dan dukungan terhadap usaha-usaha konservasi sumber daya alam serta peningkatan pendapatan masyarakat lokal.

Meningkatkan kesadaran masyarakat mengenai lingkungan telah memberikan implikasi munculnya berbagai tuntutan di semua sektor pembangunan. Tuntutan-tuntutan tersebut telah dan akan mendorong tumbuhnya usaha-usaha baru dan cara-cara pendekatan baru seperti bisnis pariwisata oleh masyarakat dalam upaya meningkatkan kesejahteraannya. Ekowisata merupakan bentuk wisata yang dikelola dengan pendekatan konservasi. Apabila ekowisata diartikan pengelolaan alam dan budaya masyarakat yang menjamin kelestarian dan kesejahteraan, konservasi merupakan upaya menjaga kelangsungan pemanfaatan sumber daya alam untuk waktu kini dan masa mendatang.

Pengembangan ekowisata pada dasarnya dilaksanakan dengan cara pengembangan pariwisata pada umumnya. Ada dua aspek yang perlu dipikirkan, yaitu aspek destinasi dan aspek market. Pemanfaatan area alam untuk ekowisata mempergunakan pendekatan pelestarian dan pemanfaatan. Kedua pendekatan ini dilaksanakan dengan menitikberatkan pelestarian dibandingkan pemanfaatan. Pendekatan lainnya adalah pendekatan pada keberpihakan kepada masyarakat setempat agar mampu mempertahankan budaya lokal dan sekaligus meningkatkan kesejahteraannya.

Wisatawan yang melakukan perjalanan wisata memerlukan berbagai kebutuhan dan pelayanan mulai dari keberangkatan sampai kembali lagi ke tempat asalnya. Sama seperti rutinitas setiap hari, wisatawan juga butuh makan dan minum, tempat beristirahat, menginap, serta alat transportasi yang membawanya pergi dari suatu tempat ke tempat lainnya menikmati keindahan alam. Untuk memenuhi kebutuhan dan pelayanan tersebut, ekowisata harus didukung oleh:

\section{Objek wisata dan daya tariknya}

Ada banyak alasan orang berwisata ke suatu daerah. Alasan yang paling umum tentunya melihat dan menikmati keindahan alam, menyaksikan budaya yang unik, atau mempelajari sejarah daerah tersebut. Intinya, wisatawan datang untuk menikmati hal-hal yang tidak dapat mereka temukan dalam kehidupan mereka seharihari. Alam, budaya, dan sejarah merupakan bagian penting dari objek ekowisata.

\section{Transportasi dan infrastrukturnya}


Wisatawan memerlukan alat transportasi, baik udara, darat, maupun laut, untuk mencapai daerah wisata yang menjadi tujuannya. Tersedianya alat transportasi merupakan salah satu kunci sukses kelancaran aktivitas pariwisata. Komponen pendukungnya tentu infrastruktur yang baik untuk mendukung kelancaran transportasi.

\section{Akomodasi}

Akomodasi merupakan tempat bagi wisatawan beristirahat maupun menginap untuk sementara waktu di suatu daerah wisata. Sarana dan prasarana akomodasi seperti hotel, homestay, guest house, villa, perkemahan, atau sejenisnya pada umumnya dilengkapi dengan fasilitas untuk makan dan minum. Wisatawan tentunya ingin tempat yang bersih, pelayanan yang baik, harga yang pantas, serta lokasi yang relatif mudah dijangkau.

\section{Jasa pendukung lainnya}

Jasa pendukung adalah hal-hal yang mendukung kelancaran berwisata, misalnya biro perjalanan yang mengatur perjalanan wisatawan, lokasi penjualan cinderamata, pusat informasi, jasa pemandu wisata, mesin ATM perbankan, jaringan internet, dan pendukung lainnya. Wisatawan zaman sekarang biasanya suka mengabadikan moment indahnya di tempat-tempat wisata menggunakan kamera handphone dalam bentuk foto dan video lalu mem-posting di media sosial, tentunya wisatawan membutuhkan jaringan internet yang lancar.

Pembangunan suatu kawasan ekowisata harus dirancang dengan bersumber pada potensi dan daya tarik yang dimiliki kawasan tersebut dengan mengacu pada kriteria keberhasilan pengembangan, yang meliputi:

1. Kelayakan finansial

Studi kelayakan finansial menyangkut perhitungan secara komersial dari pembangunan objek ekowisata tersebut. Hal ini berkaitan dengan sifat dasar bisnis pariwisata yaitu mencari keuntungan.

2. Kelayakan sosial dan ekonomi

Studi kelayakan sosial ekonomi bertujuan untuk melihat dampak sosial dan dampak ekonomi yang ditimbulkan dari pembangunan kawasan ekowisata tersebut.

3. Kelayakan teknis

Studi kelayakan teknis menyangkut pembangunan objek wisata yang harus dapat dipertanggungjawabkan keselamatan pengunjung dengan melihat daya dukung yang ada.

4. Kelayakan lingkungan

Studi kelayakan lingkungan didasarkan pada Analisis Mengenai Dampak Lingkungan (Amdal) yang dijadikan sebagai acuan kegiatan pembangunan suatu kawasan ekowisata.

Perkembangan ekowisata di suatu daerah akan terus meningkat dikarenakan jumlah penduduk yang bertambah dari waktu ke waktu, terutama jumlah penduduk dari kelompok umur remaja, serta meningkatnya pendapatan perkapita masyarakat yang berbanding lurus dengan peningkatan daya beli masyarakat. Diakui bahwa Indonesia merupakan negara dengan destinasi kawasan ekowisata yang berlimpah.

Ada dua hal penting yang harus diperhatikan oleh pengelola kawasan ekowisata. Pertama, pelayanan yang baik. Bayangkan apabila wisatawan datang dari luar kota dan merencanakan perjalanannya sedemikian rupa serta mengeluarkan uang yang tidak sedikit untuk berlibur, tapi ketika datang ke suatu daerah justru menemui supir yang tidak ramah kepada penumpang. Hal ini akan memberikan citra yang buruk bagi kawasan ekowisata tersebut. Kedua, menjaga kelestarian dan keindahan alam karena hal tersebut merupakan aset bagi sebuah kawasan ekowisata (Nugroho, 2015).

Pemerintah telah meluncurkan program Sapta Pesona Wisata. Program tersebut bertujuan untuk meningkatkan kesadaran dan rasa tanggung jawab dari seluruh lapisan masyarakat untuk mendukung kegiatan pariwisata di Indonesia. Sapta Pesona Wisata melambangkan unsur keamanan, ketertiban, kebersihan, kesejukan, keindahan, keramahan, dan kenangan dalam berwisata.

Pemanfaatan perkembangan teknologi merupakan sebuah keniscayaan bagi masyarakat Desa Mempura dalam mempromosikan potensi ekowisata yang ada di daerahnya kepada masyarakat luas, baik nasional maupun internasional (Saparita, Hidajat, dan Apriliyadi, 2019). Dalam mengembangkan sebuah kawasan ekowisata yang akan dikelola oleh masyarakat, diperlukan adanya dukungan yang nyata dari Pemerintah Kabupaten Siak sebagai wujud keberpihakan pemerintah terhadap peningkatan perekonomian masyarakat Desa Mempura. Oleh karena itu, Pemerintah Kabupaten Siak dapat membantu mempromosikan potensi ekowisata di Desa Mempura melalui website resminya maupun membuat website Desa Mempura sebagai pusat informasi mengenai kawasan ekowisata yang terdapat di Desa Mempura (Desiani, Yahdin, Irmeilyana, dan Rodiah, 2020). 
Dengan dilaksanakannya kegiatan penyuluhan hukum ini diharapkan dapat menambah pemahaman masyarakat Desa Mempura mengenai ekowisata sehingga masyarakat mampu mengembangkan potensi ekowisata yang ada di Desa Mempura untuk meningkatkan perekonomian masyarakat.

\section{KESIMPULAN}

Kebijakan Pemerintah Kabupaten Siak menutup objek wisata Istana Kerajaan Siak Sri Indrapura untuk mencegah penyebaran wabah Covid-19 berdampak terhadap perekonomian masyarakat, termasuk masyarakat Desa Mempura. Pengabdian ini bertujuan untuk membantu mengembangkan potensi ekowisata untuk meningkatkan perekonomian masyarakat Desa Mempura di masa pandemi Covid-19. Kabupaten Siak telah dikenal masyarakat, baik nasional maupun internasional, dengan objek wisata Istana Kerajaan Siak Sri Indrapura yang terkenal akan kejayaan serta peninggalan bersejarahnya yang kental dengan corak budaya Melayu yang berpadu nuansa Islam. Sebenarnya, selain wisata sejarah, bentangan alam Kabupaten Siak yang indah dan asri sangat potensial menjadi kawasan ekowisata yang menjanjikan. Apalagi di saat kondisi perekonomian masyarakat sedang memburuk akibat pandemi Covid-19 yang melanda selama beberapa bulan terakhir. Upaya yang dilakukan oleh tim pengabdi adalah memberikan penyuluhan hukum mengenai ekowisata untuk membantu masyarakat mengembangkan potensi ekowisata di Desa Mempura. Dalam mengembangkan sebuah kawasan ekowisata, diperlukan adanya dukungan yang nyata dari Pemerintah Kabupaten Siak sebagai wujud keberpihakan pemerintah terhadap peningkatan perekonomian masyarakat.

\section{DAFTAR PUSTAKA}

Achlis. 1988. Masyarakat dan Kebudayaan. Bandung: STKS Bandung.

Desiani, A., Yahdin, S., Irmeilyana, dan Rodiah, D. 2020. Inovasi Digitalisasi Promosi Potensi dan Produk Usaha Masyarakat Desa Berbasis Website di Desa Bangsal Kecamatan Pampangan. Riau Journal of Empowerment, 3 (1), 49-59. https://doi.org/10.31258/raje.3.1.49-59

Effendi, T. N. 2000. Pembangunan, Krisis, dan Arah Reformasi. Surakarta: Muhammadiyah University Press.

Fahrial, Utama, A. S., dan Dewi, S. 2019. Pemanfaatan Corporate Social Responsibility (CSR) terhadap Pembangunan Perekonomian Desa. Jurnal Wawasan Yuridika, 3 (2), 259-272.

Fauzi, M., Sumiarsih, E., Adriman, Rusliadi, dan Hasibuan, I. F. 2020. Pemberdayaan Masyarakat Melalui Pelatihan Pembuatan Ecobrick sebagai Upaya Mengurangi Sampah Plastik di Kecamatan Bunga Raya. Riau Journal of Empowerment, 3(2), 87-96. https://doi.org/10.31258/raje.3.2.87-96

Hikmat, H. 1995. Paradigma Pembangunan dan Implikasi dalam Perencanaan Sosial. Jakarta: Universitas Indonesia.

Nugroho, I. 2015. Ekowisata dan Pembangunan Berkelanjutan. Yogyakarta: Pustaka Pelajar.

Saparita, R., Hidajat, E. W., dan Apriliyadi, E. K. 2019. Pengembangan Ekonomi Desa Penghasil Kopi Melalui Pemanfaatan Ilmu Pengetahuan dan Teknologi di Kabupaten Belu. Riau Journal of Empowerment, 2 (2), 81-91. https://doi.org/10.31258/raje.2.2.81-91

Sunaryo, B. 2015. Kebijakan Pembangunan Destinasi Pariwisata; Konsep dan Aplikasinya di Indonesia. Yogyakarta: Gava Media.

Utama, A. S. 2017. Eksistensi Nagari di Sumatera Barat sebagai Desa Adat dalam Sistem Ketatanegaraan di Indonesia Berdasarkan Undang-Undang Nomor 6 Tahun 2014 tentang Desa. Jurnal Equitable, 2 (1), 75-93. 